\title{
Basic medical science takes home the trophies
}

With the arrival of fall also comes biomedical research awards. Two of the most coveted, the Lasker Awards and the Nobel Prize for medicine and physiology, went to scientists who have provided fundamental understandings of development and immunology.

The 1995 Albert Lasker Medical Research Awards were presented on 29 September in New York City. Founded by Albert and Mary Lasker to increase public awareness about medical research and to encourage continued federal funding, the Lasker Medical Research Awards celebrated their fiftieth birthday. In short acceptance speeches, all the research award recipients expressed gratitude to the Lasker Award jury for the honour, to colleagues and families for intellectual and emotional support, and to governmental organizations for the financial backing that allowed them to make the discoveries for which they were honoured.

The Basic Medical Research Award was shared by five researchers who together laid the foundation of modern immunology: how $\mathrm{T}$ cells recognize and respond to foreign antigens. Peter C. Doherty of St Jude Children's Research Hospital in Memphis, Jack L. Strominger and Don C. Wiley, both of Harvard University, Emil R. Unanue of Washington University School of Medicine in St Louis, and Rolf M. Zinkernagel of the University of Zurich were honoured with awards.

I think several general lessons can be drawn from our [Doherty's and Zinkernagel's] experience, said Doherty in his acceptance remarks. "We were working in Canberra, Australia, which is not an intellectual vacuum by any sense, but it is a long way from major research centres in North America and Europe," he said, "Thus, you can't predict where scientific discovery will happen." Doherty also emphasized the fact that the "science is truly international. You see it here in the group rewarded here; two Australians, one Swiss and three
Americans or people that have worked in America from various backgrounds; though perhaps that's too many Australians for most people."

The Clinical Medical Research 1995 Nobel Prize in medicine or physiology, from left: Eric F. Award was pre- Wieschaus, Christiane Nüesslein-Volhard and Edward B. Lewis. sented to Barry J.

Marshall of the University of Virginia Medical Center for his well-documented studies that proved that a bacterium, Helicobacter pylori, caused gastritis and gastric ulcers, making it the most common chronic infection worldwide. Marshall regaled the audience with his explanation of why he didn't name the bacteria after himself, as is often the case with discoverers of new microbes. "We initially thought it was sexually transmitted," he said, citing studies they did in prostitutes with a high percentage testing positive for $H$. pylori. Marshall said that they learned otherwise when an intern of his, a nun from the order of St John of God, discovered four positive tests from other sisters and the chaplain of her order. "We later found out they were all Irish [H. pylori is highly prevalent in Ireland]," he said, adding that by the time this disproved the sexualspread hypothesis, the bacteria was already named.

Finally, the Public Service Award was presented to Senator Mark O. Hatfield (Republican, Oregon) and accepted on his behalf by his wife, Antoinette. The award citation mentioned Hatfield's energetic leadership and enduring advocacy in support of biomedical research.

The fiftieth anniversary ceremony was attended by nearly one hundred previous award recipients. In the fifty years of the Lasker Awards, over 300 awards have been presented, and 54 of the winners have also gone on to win Nobel Prizes.

In fact, two previous Lasker Award win-

\author{
IMAGE \\ UNAVAILABLE \\ FOR \\ COPYRIGHT \\ REASONS
}

ners shared with a third scientist the 1995 Nobel Prize in medicine or physiology. Edward B. Lewis of the California Institute of Technology and Christiane NüessleinVolhard of the Max-Planck Institute for Developmental Biology in Tüebingen, Germany, winners of the 1991 Lasker Basic Medical Research Award, as well as Eric F. Wieschaus of Princeton University were honoured for their work in deciphering the genetic instructions that determine basic body plans in early embryos. Most of the work cited was carried out in the fruit fly, Drosophila melanogaster.

Starting in the late 1930s, Lewis designed a series of elegant, and mind-numbingly convoluted, genetic experiments by which he was able to show that certain genes, or rather certain groups of genes, ultimately controlled the basic body plan of the adult fly. These are now known as homeotic genes, some of which are remarkably wellconserved in mammals. Wieschaus and Nüsslein-Volhard looked earlier in development, trying to identify the genes involved in turning a newly fertilized egg into an embryo. Their work, begun in the late 1970s, has spawned immense interest among developmental biologists working on animal models of all kinds.

The winners will receive their awards in Stockholm on 10 December, the anniversary of the death of Alfred Nobel. They will share, in addition to the eminence that accompanies the award, a stipend of approximately US\$1 million.

FINTAN R. STEELE
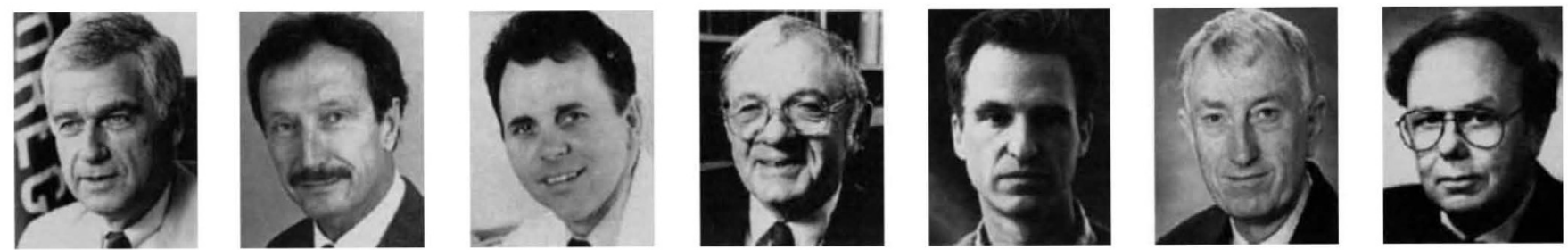

1995 Albert Lasker Medical Research Awards recipients, from left: Mark O. Hatfield, Rolf M. Zinkernagel, Barry f. Marshall, Jack L. Strominger, Don C. Wiley, Peter C. Doherty and Emil R. Unanue. 